\title{
酵母の食用化に関する研究 (I)
}

Studies on the Utilization of Dry Yeast for Food Materials (I)

酵母添加料理の献立と酵母の添加限界

Recipes for Cooking Foods mixed with Dry Yeast and

Moderate Mixture Ratio of Dry Yeast to Foods

（昭和 35 作 2 月 8 日受理)

\author{
石 井 隆一 郎 \\ ( Ryuichiroh Ishii) \\ 田中綾 \\ (Aya Tanaka)
}

$\underset{\text { (Iso Ohta) }}{\text { 太田 }}$

柅原 久美子

(Kumiko Kanbara)

Thirty-four kinds of recipe of cooking foods were studied for eating dry yeast (Mycotorula japonica) grown on sulfite waste liquor.

As the dry Yeast powder has a slightly bitter taste, a moderate mixture ratio of the yeast to foods depended on the original flavor of the cooked foods.

The mixture ratio of the yeast powder was following; Mustard 25\%, Mustard-vinegar miso (fermented bean paste mixed with mustard \& vinegar) $11 \%$, fish and beast meats, $3.6-5 \%$, flour and cereal starch $2.9 \%$, Deep-fat fried foods $2.2 \%$, cakes $2.2 \%$ and soups $0.9 \%$.

$$
\text { 緒 言 }
$$

食飼料用酵母の製造及びその栄養学的価值を検討した 報告は内外共に古くから非常に多い。食品の栄荃価は， 食品の価值判断のもっとも重要な要因であるからこの方 面の研究が進められることは誠に喜ばしいが, 一方食品 としての品質特に香, 味など嗜好の面も忘れられてはな らない。この嗜好の面との関連において酵母の食品への 加工を論した報告は案外少なく「醉母は多くの食品に添 加使用出来る」といった程度1の简単な記述が多い。著 者なとはこの方面の险路を唡郡して行きたいと考えてい るが今回は乾燥酵を添加した 34 種類の料理の献立を作製 試食し, 従来の啫好を変えないで添加出来る酵母の配合 割合を献立別に整理してみた。

\section{実験材料と実験方法}

乾嬠酵母 (Mycotorula japonica) 粉末は単味で試食 すると, やや芳んばしい焦臭と共にわずかに旨味を感ず るが，後には徐々に苦味が現われ，味覚に敏感な女子に は，たまには胸やけや不快感をもよおさしめる原因にな る。苦味成分は後報のように脱苦味処理によりかなり除 去できるがこの操作によってビタミン B複合体やアミノ 酸などの水溶性物質の流出をともならから乾嬠酵母をそ のまま食用とすれば栄趇成分の損失はそれだけ防止でき
るわけである。今回は乾嬠瞃母を無処理のまま各種の献 立の一材料として使用した。献立は一般に一食分とし, 特別の場合には数食分をつくり, 試食してその献立のも つ持味を変えない程度の酵母の最高添加量を決めた。

\section{献立の玨類による醂母の添加割合}

献立に使用した各種材料や調理方法は煩雑をさけるた めに省略し，料理名と醭母添加\%を第 1 表にかかげ た。表中, 総最は出来上り総量をさし, 主混合物は酝母 の添加された食品をさす。

すなわち献立中酵母の添加可能と思われる食品例えば 肉製品デンブなどに添加し，これを用い他の材料ととも に一つの献立をつくる。例えば料理名 No. 10 のサーモ ンコロッケと野菜ソテーではコロッケに $3.6 \%$ の割合で 酵母が加えられており，この献立の総重量の $2.1 \%$ にあ たる。この程度の制合では味覚特に苦味や醉母奥に敏感 な者を除いては醉母の添加はその献立のもつ持味を変え ることはないが進んで食味を向上せしめるとはいえな い。ただ肉を材料とする献立やカレーでは味をやや淡 く，重くする傾向にあり一部の人々の評では添加した方 がよいとの結果をえた。

ただ（本実験は昭和 31 年度に行なったもので，その 後, 乾燥醉母の品啠も向上しているから添加量を増加才 ることも可能であろ5。) 
第 1 表 酵 添加献立例 (1 食分)

\begin{tabular}{|c|c|c|c|c|c|c|c|c|c|}
\hline 種類 & No. & 理 & 総 & 量 $\mathrm{g}$ & 酵 & 母 & 酵母/総骨\% & 酵 母/主混台 & 合物 \% \\
\hline \multirow{4}{*}{ 蛙 } & 1 & フーカデンとボテトのチーズやる & & 321 & & 3 & 0.94 & 肉 & 2.8 \\
\hline & 2 & 梅ヤ き ミート & * & 529 & & 10 & 1.9 & 肉 & 3.5 \\
\hline & 3 & ミンチボールの三色ソーストースト & * & 420 & & 5 & 1.2 & ボール & 3.7 \\
\hline & 4 & トマトサーデのハンバークステーキ & & 259 & & 3 & 1.2 & 肉 & 3.2 \\
\hline \multirow[t]{2}{*}{ 物 } & 5 & 䡈 & & 223 & & 2 & 0.9 & 皮 & 2.8 \\
\hline & 6 & 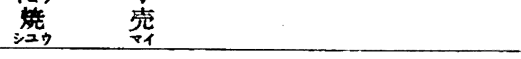 & & 219 & & 1 & 0.46 & 皮 & 3.0 \\
\hline \multirow{3}{*}{ 掦 } & 7 & 茄子のはさみ揚げ & & 163 & & 2 & 1.2 & はさみ & 4.4 \\
\hline & 8 & けんちん揚げと紅莱扔ろし & & 163 & & 3 & 1.8 & 掦 物 & 2.6 \\
\hline & 9 & 巻秋刀魚のフライと粉吹苸刻みキャベッ & & 258 & & 2 & 0.78 & 掦 物 & 1.7 \\
\hline \multirow{2}{*}{ 物 } & 10 & サーモンコロンケと野菜ソテー & & 258 & & 6 & 2.1 & コロッヶ & 3.6 \\
\hline & 11 & 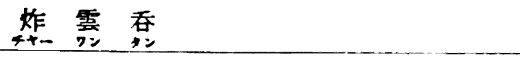 & & 49 & & 0.5 & 1.0 & 皮 & 2.8 \\
\hline \multirow{2}{*}{ 若 } & 12 & ふろふさ大根篎そほろあんかけ & & 142 & & 1 & 0.7 & 肉のあん & 5.0 \\
\hline & 13 & 勾のからまぶし & & 143 & & 3 & 2.1 & 卵の花 & 4.8 \\
\hline \multirow{2}{*}{ 物 } & 14 & サーデンボールのホワイトソース竟 & & 428 & & 3 & 0.7 & ボール & 4.2 \\
\hline & 15 & 鲔のフレーク味付でんぶ & * & 225 & & 11.3 & & テンンフ & 5.0 \\
\hline \multirow{3}{*}{ it } & 16 & to こ $\varepsilon$ it & & 319 & & 2 & 0.63 & 汁 & \\
\hline & 17 & 粕 汁 & & 370 & & 2 & 0.5 & 汁 & 0.8 \\
\hline & 18 & さつま 汁 & & 340 & & 2 & 0.6 & 汁 & 0.9 \\
\hline \multirow{2}{*}{ 物 } & 19 & オニオンスープ & & 297 & & 2 & 0.7 & スープ & 0.9 \\
\hline & 20 & 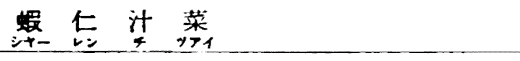 & & 269 & & 1 & 0.4 & 掦 物 & 1.5 \\
\hline \multirow{2}{*}{$\begin{array}{l}\text { 和 } \\
\text { 兄 } \\
\text { 物 }\end{array}$} & 21 & ほうれん草の辛子油和え & & 58 & & 2 & 3.5 & 辛子 & 25.0 \\
\hline & 22 & わけをといかの辛子酢みそ和え & & 79 & & 2 & 2.5 & 辛子酢みそ & 10.5 \\
\hline パン & 23 & カレーサンドウィンチ & & 327 & & 2 & 0.5 & 肉野菜 & 3.3 \\
\hline 梦 & 24 & 緑类の黄金蒸し & & 245 & & 2 & 0.8 & 䵀 & 3.6 \\
\hline 饭 & 25 & 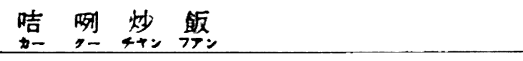 & & 409 & & 3 & 0.7 & 飯 & 2.0 \\
\hline 鮩 & 26 & 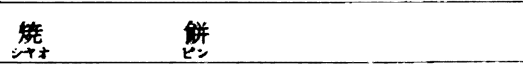 & & $\begin{array}{r}46 \\
30 \\
\end{array}$ & & $\begin{array}{l}1 \\
1 \\
\end{array}$ & $\begin{array}{l}2.2 \\
3.3 \\
\end{array}$ & $\begin{array}{l}\text { 皮 } \\
\text { 皮 }\end{array}$ & $\begin{array}{l}3.1 \\
6.3 \\
\end{array}$ \\
\hline \multirow{4}{*}{ 莧 } & 27 & 桃 & $*$ & 181 & & 2 & 1.1 & 皮 & 2.5 \\
\hline & 28 & 溥 皮 鮼 頭 & & 391 & & 5 & 1.3 & 皮 & 2.6 \\
\hline & 29 & 落西 & * & 201 & & 5 & 2.5 & & - \\
\hline & 30 & スポンチヶーキ & * & 350 & & 5 & 1.4 & ケーキ & 1.5 \\
\hline \multirow{4}{*}{ 子 } & 31 & ドーナツ & $*$ & 209 & & 5 & 2.4 & & - \\
\hline & 32 & $\eta=\neq-$ & * & 233 & & 5 & 2.2 & & - \\
\hline & 33 & スィートポテト & & 123 & & 3 & 2.4 & & - \\
\hline & 34 & シェークリーム & $*$ & 821 & & 11 & 1.4 & $\dot{*}=-$ & 2.0 \\
\hline
\end{tabular}

*：混合割合（数食分）

総

括

以上の成績を要約すると,

1）乾燥睹母を献立の一材料として用いる場合，その 献立の持味をそこなわない程度の最高混和割合を献立の 種類別に分けてみると第 2 表のよらである。

2）一食分で醉母を出来るだけ多く使用出来る献立は No. 10 のサーモンコロッケと野菜ソテーで $6 \mathrm{~g}$ ，薄皮鏝
頭 $5 \mathrm{~g}$ でその他は 2 3g である。

3）試食の結果上記程度の添加量では特にその献立の 持味は変らないがさらに風味を向上するとは考えられな い。しかしカレー, 肉類などは添加により味を濃く重く する上の批評もあった。

4) 以上の結果は味覚に敏感な調理担当の女子試食者 の意見によったが男子の場合または食習慣によりさらに 酵母を増量することも可能であろう。 
第 2 表 乾燥醉母添加限界

\begin{tabular}{|c|c|c|c|}
\hline 献立の種類 & 主 材 料 & $\begin{array}{l}\text { 主混合物 } \\
\text { 中醭母 } \%\end{array}$ & 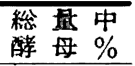 \\
\hline \multirow{2}{*}{$\begin{array}{l}\text { 最も多く混和 } \\
\text { できる献立 }\end{array}$} & 辛 子 & 25 & 3.5 \\
\hline & 辛子釄みそ & 10.5 & 2.5 \\
\hline \multirow{3}{*}{$\begin{array}{l}\text { 鳥獸魚肉を主 } \\
\text { とする献立 }\end{array}$} & 内の多い場合 & 5 & $0.7 \sim 5.0$ \\
\hline & 内の普通の場合 & $2.8 \sim 4.4$ & $0.5 \sim 2.1$ \\
\hline & 普通の場合平均 & 3.6 & 1.2 \\
\hline 殸椇を主とす & & $\begin{array}{r}2.0 \sim 3.6 \\
(6.3)\end{array}$ & $0.8 \sim 2.2$ \\
\hline る献立 & 同上平均 & 2.9 & 1.2 \\
\hline \multirow{2}{*}{ 物 } & & $1.7 \sim 2.6$ & $0.8 \sim 1.8$ \\
\hline & 同上平均 & 2.2 & 1.2 \\
\hline \multirow{2}{*}{$-\quad \neq$} & 皮 & $1.5 \sim 2.5$ & $1.1 \sim 2.5$ \\
\hline & 同上平均 & 2.2 & 1.8 \\
\hline \multicolumn{2}{|l|}{ 汁 物 } & $0.8 \sim 0.9$ & $0.5 \sim 0.7$ \\
\hline
\end{tabular}

5）現在の酵母はや苦味をのこすからこれを脱苦味 すればさらに多量の睹母食用として添加することがで きる。

（本報告は茶珍，久保両博士のご指導により行なった もので炤和34年11月 6 日イースト工業会技術想影会にて 㴋演した。なお酵母の恵与をうけた東洋紡績三輸万治氏 に謝意を表します。)

\section{文献 \\ 1) 齐藤 糊訳：酵母の科学 p. 65 (1957) 三共出版} （大阪市立街生研究所）

\section{中程及ひ生地発醂中における各種の糖の消品}

発醉中の中種, 生地や姺上ったパンについて，各種の 糖を定量すると同時に，チモタキグラフでその間のガス 発生量を求のて，糖が発酵中にどのように消費されるか

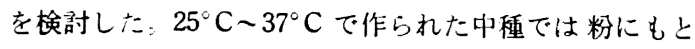
もと含まれる葡萄糖と果糖がほほ同時にまず消資され， それらがある浱度以下にへると麦芽榶が增加し，次いで 急激に減少する。ガス発生量の変化もこれを裹付け，监 糖類の消費が進んだ時期と，酵母が麦芽桾発酵を行なう ようになった時期とに発生量のピークが認められる。麦 芽糖の減少は糖添加の有無, 添加された糖の種類や鼠に
あまり関倸なく認められるが，最初の分間のガス発生量

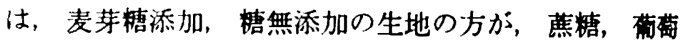
糖，果榶の場合より大である。 $25^{\circ} \mathrm{C}$ で発酵させた中秛 は，37`Cの場合にくらべて，特に麦芽糖添加生地の場 台、第三発醉が促進された。

The Fate of Various Sugars in Fermenting Sponges and Doughs.

by J. W. Lee ct al: Cereal Chem. 36, 522 (1959) (安 永)

\section{自動酸化ラート・綿実油からの分別エステルのラッテにおよはす影新}

ラード・綿尖油を 95 100 C, 210 時間加熱し, 分子蒸 溜在行ない,ケン化, 酸性とし,エスルエステルを作った。 ラードの分子蒸溜溜出部エステルは, 蒸溜して, 溜出部, $160 \sim 180^{\circ} \mathrm{C} 3 \mathrm{~mm}$ 溜出部 (F-2) 扩よび残留部とし, F.2 は尿素分別を行って, 付加物生成部と非生成部とに分け, 各々を更に蒸溜して分別した。また分子蒸溜残留部エス テルは,分子蒸溜を行ない分別した。綿実油についても， ほほ同様の方法により分別を行い, ラッテに飼料の $8 \%$ をあたえて, 体重, 肝・腎重量, 肝・血清コレステロー ル量を測定し，また酸価等老測定した。ラッテの生長を 減少させるフラクションは, ラード・綿実油の, 分子蒸
溜残留エステルー分子蒸溜溜出部で, いずれも $-\mathrm{OH}$ 酸 素鼠か，他のフラクションより多く， $\mathrm{C}_{18}$ の三量体およ び二量体と考えられる。また陑有毒部分は，肝・血清コ レステロール量を減少させた。

Influence of feeding fractionated esters of autoxidized lard and cottonseed oil on growth, thirst, organ weight, and liver lipid of rats.

by Hans Kaunitz et al.,

J. Am. Oil Chem. Soc., 36, 611 (1959)

(土 屋) 